The Geneva Papers on Risk and Insurance, 19 (No. 70, January 1994), 22 - 36

\title{
Prices, Distribution Channels and Regulatory Intervention in European Insurance Markets
}

\author{
by J. Finsinger* and F. A. Schmid*
}

\section{Introduction}

The 'Cost of Non-Europe' reports suggest that the opening of European national financial services markets will benefit consumers by increasing competition. But these gains are only some of the potential consumer benefits that may result from European market integration. The EC-member countries have developed quite different schemes of insurance market regulations. Except for an agreement on some basic aspects such as solvency regulations, a harmonisation of the national rules of insurance market regulations was not achieved. For the time being, some markets continue to be highly regulated while others remain relatively unregulated. When freedom of service will finally be realised in Europe, insurance contracts written under different regulatory rules will compete with each other. Ultimately, as the volume of exports grows, the national regulatory rules will be put to the market test. This paper will provide an empirical analysis of how regulatory schemes affect key market characteristics and thus contribute to an understanding of the forces unleashed by the freedom of service program.

Numerous studies which deal with the influence of regulation on insurance premiums have been carried out for the US. ${ }^{1}$ A price level index is chosen; typically the inverse of the loss ratio, premium divided by the benefits paid to consumers, is analysed. The larger the proportion of premiums paid out as benefits to policy holders, the lower the price of the insurance is considered to be. A drawback of this approach is that price differences that are due to quality differences cannot be controlled for if no suitable measure of product quality is available. ${ }^{2}$ In this paper, the problem of product differentiation was avoided by considering a single and well-defined homogeneous product which is pure risk life insurance. The premiums of this product in highly regulated countries can be shown to exceed the premiums in less regulated countries by 117 percent.

\footnotetext{
* University of Vienna, School of Social and Economic Sciences, Berggasse 17/17, A-1090 Vienna, Austria. We wish to thank Martina Venz for providing excellent research assistance. Financial support from the German Science Foundation (DFG) and the Ludwig Boltzmann Institute, Vienna, is gratefully acknowledged.

1 See the survey by Harrington (1984).

${ }^{2}$ A study which takes quality variations into account is that by Pauly, Kunreuther and Kleindorfer (1986).
} 
The distribution channels that are used for the marketing of insurance products, "carry" different kinds of information and are therefore crucial for the consumer's purchase decisions. Since the national supervisory systems are meant to protect the imperfectly informed customers, the merits of these systems can be assessed by looking at the market shares of the various distribution channels. In the following, the market shares of various types of distribution channels such as brokers, multiple agents. exclusive firm agents, direct marketing and banks are presented for ten EC-member countries. The analysis will show that in highly regulated environments, distribution channels which provide less information to consumers tend to dominate. Moreover, it will be shown that regulation fosters concentration and leads to more stable market shares.

\section{Regulatory intervention in EC-insurance markets}

All EC-insurance markets are regulated in some respect: there are entry controls, minimum capital and reserve requirements as well as specified legal rules on insurance contract language. In some countries, additional rules are in effect such as price regulation and contract standardisation which are meant to be beneficial to the customer. ${ }^{3}$

When signing an insurance contract, the customer faces a severe information problem concerning the solvency of the insurer. There are three ways to correct this potential market failure. Firstly, information on company solvency can be supplied to the consumer by the regulatory agency. Secondly, the consumer can be insured against the failure of insurance companies by a guarantee fund which manages insurance company failures and pays the claims of their customers. Thirdly, price competition can be reduced with the objective of making failures an unlikely event: prices are regulated or, somewhat less common, price collusion is permitted. The instruments of price regulation range from discretionary intervention into the pricing strategy of insolvent firms to mandatory premium calculation rules (such as mark-up pricing) for all firms in the market. In a few countries, such as Germany and Switzerland, premiums for certain insurance products are set at a uniform level which is sufficiently high so as to prevent company failures. Constraints on price competition result in increased non-price competition. This is why price regulation usually is complemented with product standardisation.

Several surveys of the regulatory frameworks for EC-member countries show that there are only three countries which strongly rely on market forces and keep regulatory intervention to the absolute minimum. These countries are the Netherlands, the United Kingdom ${ }^{4}$ and Ireland.

\section{A survey of distribution channels in selected european countries}

Insurance companies have a number of options when they choose their distribution channels. They can build up a network of exclusive agents, they can choose to sell directly to consumers, they can try to use other outlets such as car-dealer, banks, mail order houses or they can sell via independent agents such as brokers.

As Table 1 shows, market shares of different distribution channels differ much among countries. There are only two countries in which, as far as we know, insurance is not sold by exclusive agents : the Netherlands and Ireland.

\footnotetext{
3 For a comprchensive overview see Finsinger and Pauly (1986) and Finsinger, Hammond and Tapp (1985).

4 See Anderson Consulting (1990, p. 3) and v.d. Berghe (1989, p. 214).

5 See Ellis (1990).
} 
Table 1:

Market shares of distribution channels in European countries in 1987

\begin{tabular}{|l|c|c|c|c|c|}
\hline & Germany & Italy & Ireland & Denmark & France \\
\hline Exclusive Agents & 79.0 & 56.0 & & 50.0 & 42.0 \\
\hline Banks & $2.0^{6}$ & & 15.0 & & 16.0 \\
\hline Brokers & 16.0 & 15.0 & 85.0 & & 23.5 \\
\hline Multiple Agents & & 29.0 & & & \\
\hline Direct Marketing & 3.0 & & & 50.0 & 18.5 \\
\hline & & & & & \\
\hline Total & 100.0 & 100.0 & 100.0 & 100.0 & 100.0 \\
\hline & Luxembourg & Belgium & United & Nether- & Spain \\
\hline Exclusive Agents & 95.0 & 25.0 & 37.0 & & 87.1 \\
\hline Banks & & & 1.5 & 13.0 & \\
\hline Brokers & & 65.0 & 57.0 & 20.0 & 12.9 \\
\hline Multiple Agents & & & 3.0 & 42.0 & \\
\hline Direct Marketing & 5.0 & 10.0 & 1.5 & 25.0 & \\
\hline & & & & & 100.0 \\
\hline Total & 100.0 & 100.0 & 100.0 & 100.0 & \\
\hline
\end{tabular}

Sources: L'Argus, Journal international des assurances, No. 6111, 1989; own survey.

In Germany and in Luxembourg, exclusive agents are the main distribution channel while their market shares in Belgium and the United Kingdom are rather small. Brokers play a dominant role in Belgium and the less regulated countries such as Ireland and the United Kingdom.

Table 1 must be interpreted with care since the figures appear to be crude estimates. In addition, they do not discriminate between private and commercial insurance business. In countries where brokers have a market share of 20 percent or less, this share mostly reflects commercial insurance business while private insurance business is sold via other distribution channels.

${ }^{6}$ More recently, the banks have stepped up their efforts to sell insurance. With a few exceptions (such as the Deutsche Bank which has established its own life insurance company), the banks only channel business to regular insurance companies. 
The distribution channels can be classified into two distinct groups. It is generally held that networks of exclusive firm agents use distinct selling techniques and build up strong 'policy holder - financial intermediary' relationships as compared to brokers or multiple firm agents. Exclusive firm agents or banks only sell the product of one company ${ }^{7}$ and therefore have no incentive to pass on information on the shortcomings of this company's products compared to the products of competing companies. Hence, an exclusive firm agent or a bank is a source of one-sided information.

All other distribution channels either provide information on more than one company's products or do not actively approach the consumer, as is the case with direct marketing outlets. In the former case, the consumer obtains some amount of impartial advice, in the latter case, he is the one who must search for price and product quality information and, as a result, he is the one who must choose the direct insurer's office to cover his risk. Insurance sold by direct marketing invariably is low price insurance. Since customers who choose to buy from a direct marketing outlet tend to be informed about the market a priori, they do not need advice on other companies' products at the time of purchase.

In view of these arguments, the state of the buyer-insurer relationship in the European countries could be characterised by the market share of the tied advice distribution channels, given in Table 2 .

$\begin{array}{lc}\text { Table 2: Market shares of tied advice distribution channels in Europe in } 1987 \\ \text { Country } & \text { Tied Advice Distribution Share } \\ \text { Germany } & 81.0 \\ \text { France } & 58.0 \\ \text { Italy } & 56.0 \\ \text { Spain } & 87.1 \\ \text { Denmark } & 50.0 \\ \text { Luxembourg } & 95.0 \\ \text { Belgium } & 25.0 \\ \text { United Kingdom } & 38.5 \\ \text { Netherlands } & 13.0 \\ \text { Ireland } & 15.0\end{array}$

\section{The relationship between distribution channels and the regulatory intensity}

In the less regulated countries such as Ireland, the Netherlands and the United Kingdom, the market share of tied advice is small. This indicates that countries which aim to protect consumers by means of strong and restrictive regulation of the insurance business thereby promote distribution channels which provide selected and limited advice rather than impartial advice. This hypothesis is consistent with findings which show that excessive regulation is self-defeating and ultimately harms the consumer. ${ }^{8}$

\footnotetext{
${ }^{7}$ Even in the UK, the majority of banks have chosen to become tied agents for the sale of life insurance.

${ }^{8}$ See Finsinger and Pauly (1986) and Finsinger, Hammond and Tapp (1985). See also Eisen, Müller and Zweifel (1993, pp. 39-40).
} 
A recent experience in the United Kingdom may serve as an illustration. The Financial Services Act became effective in the middle of 1988, a year after our data set was collected. It was meant, amongst other things, to promote access to impartial advice for investors and insurance purchasers. The regulations require all types of intermediaries to give the best advice possible in the sense of understanding the customer's needs and selecting the appropriate type of product. But only independent intermediaries also have to offer the best available product on the market and have to disclose the amount of commission they obtain from the insurers. The effect of these regulation was that about 40 percent of the previously independent brokers decided to avoid the stringent standards by associating themselves with one company and thereby becoming a tied agent. The regulations that were intended to provide better information to consumers resulted in limiting the amount of impartial advice available in the insurance market.

Regulations affect distribution channels in various ways. In some countries, there are requirements that certain vital information about the insurance contract must be passed on to the customer. Certain types of hard selling or "cold calling" are deemed to be illegal. Restraints on price competition also have an impact on marketing. If a firm cannot attract business through low prices, it must compete in other dimensions. As price regulation leads to excessive non-price competition, additional regulations are put into place to deal with the consequences. Thus, excessive product differentiation is prevented by contract regulation and contract standardisation. Commissions to agents are regulated as well, frequently by the means of setting maximum commissions. Where prices are regulated, the agents are prevented from sharing their commissions with the policy-holders, because the latter would stimulate price competition and might thwart the regulators' efforts to prevent firm failures by keeping the price level high.

\section{Econometric analysis}

\subsection{A four-equation model}

In this section, we address the question how regulatory intervention affects premium levels, the market share of tied advice, the variability of market shares of firms, and the market concentration. The estimated four-equation model is given in Table 3 . Since this system of equations is recursive, consistent estimators could be obtained by applying ordinary least squares. The countries which were included in the regression are Germany, France, Italy, the Netherlands and the United Kingdom. ${ }^{9}$

The first equation explains the level of premiums (PREM) as a function of the intensity of regulation (REG), concentration (HERF), the market share of tied advice distribution channels (TDIST), life expectancy (LIFEEXP) and the interest rate (INTER). The variable REG captures the direct ${ }^{10}$ effect of regulation on the premium level. Since tied advice distribution channels provide less information service to the customer, tied agents should face lower costs per contract compared to independent agents. On the other hand, because less price information is offered, there is less market transparency, facilitating higher prices. Thus, the sign of the coefficient of TDIST depends on the relative strength of these two opposite effects.

${ }^{9}$ Complete data sets for other EC-countries were not available.

10 There are two indirect effects through the concentration and distribution channel variables HERF and TDIST, which are also dependent on the regulatory intensity REG (see Equations 2 and 4 ). 
Table 3: Structural equations and expected signs of coefficients

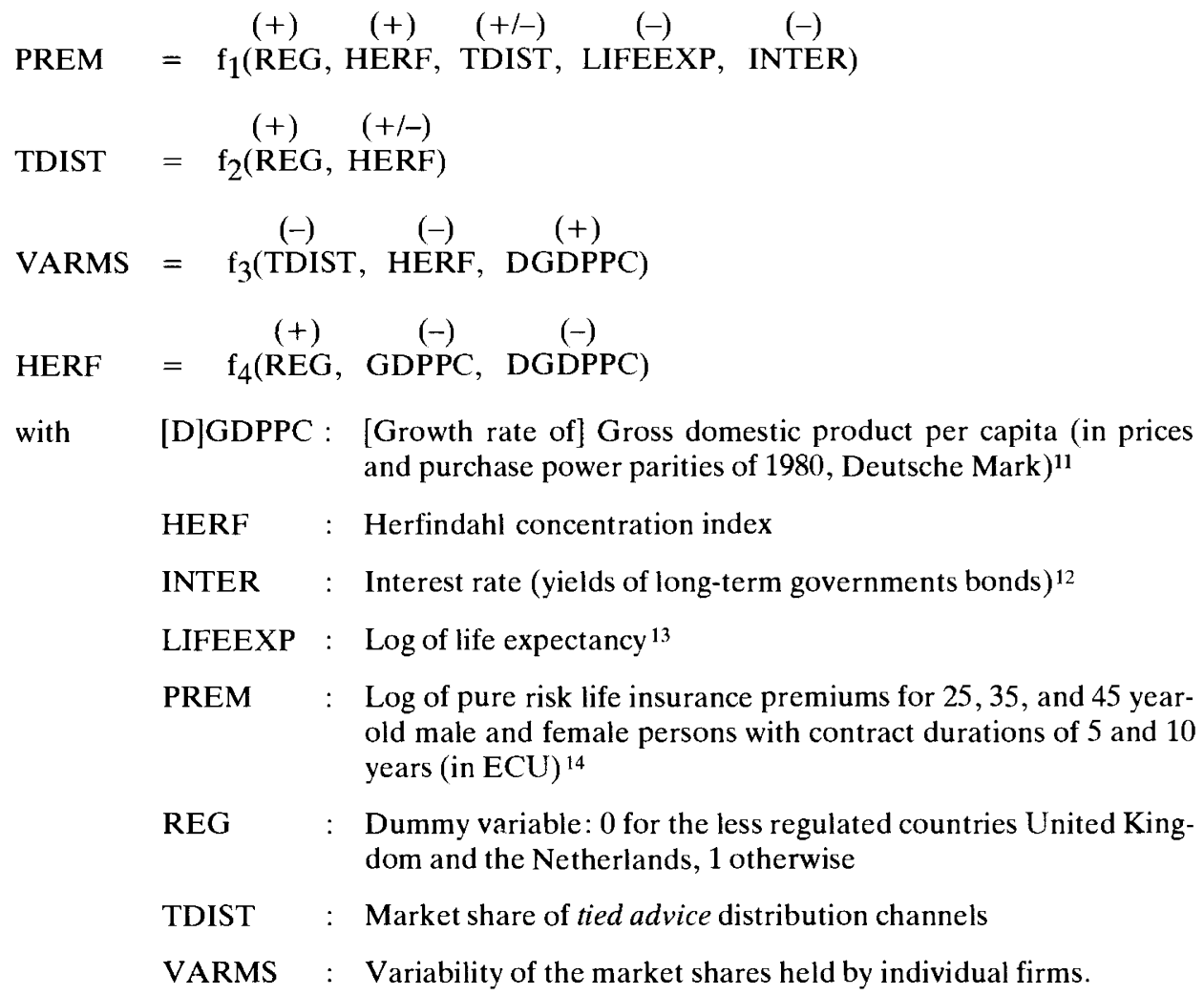
old male and female persons with contract durations of 5 and 10 years (in ECU) ${ }^{14}$

REG : Dummy variable: 0 for the less regulated countries United Kingdom and the Netherlands, 1 otherwise

TDIST : Market share of tied advice distribution channels

VARMS : Variability of the market shares held by individual firms.

Market share variability VARMS is measured by the sum of absolute values of market share changes over all companies relative to the previous period:

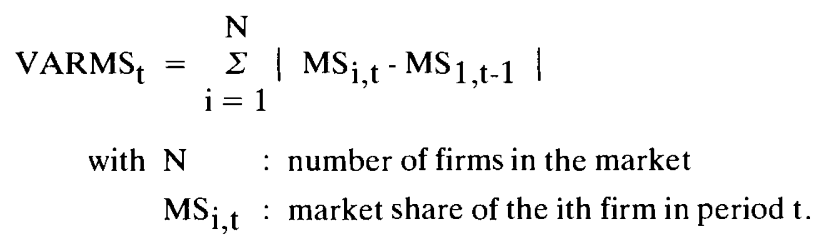

1 Source: Statistisches Bundesamt (1990).

${ }^{12}$ Source: United Nations (1990a).

${ }^{13}$ Source: United Nations (1990b). For Luxembourg the data set had to be completed by linearly interpolating between two neighbouring classes.

${ }^{14}$ Source: Price-Waterhouse (1988). 
Moreover, two cost factors are controlled for in the first equation: life expectancy and the interest rate. Since a higher life expectancy means lower expected benefits paid out to the insured, it will lead to lower premium levels. A higher interest rate allows for lower premiums as well. The life insurance companies receive the premiums yearly at the beginning of the contract period, while death on statistical average occurs in the middle of this period. During this time interval, the premium can be invested and a return proportional to the interest rate can be earned.

The second equation relates the market share of tied advice (TDIST) to regulation (REG) and to concentration, as represented by the Herfindahl concentration index (HERF). The variable REG represents a twofold influence. As the first structural equation shows, it represents the effect of regulation on the premium level at a given market structure. Moreover, regulation is expected to influence the role which alternative distribution channels play as information intermediaries. Since price regulation is usually accompanied by a standardisation of contracts, regulation reduces the need for independent information and thus should foster tied advice distribution channels. In a similar vein it can be argued that consumers demand more information in highly concentrated markets, since in these markets bad products are more likely to survive. However, highly concentrated markets may at the same time be markets with little product diversity which reduces the search costs for consumers. Besides these two demand side effects, there is also a supply side effect: firms in more concentrated markets should be more easily able to reduce competition by reducing the amount of independent advice available to consumers.

In the thirs equation, martket share variability (VARMS) is explained by the market share of tied advice (TDIST), by concentration (HERF) and by the growth rate of the gross domestic product per capita (DGDPPC). Market share variability should be greater in more competitive markets. Therefore, the coefficient of HERF is expected to be negative. Changes in product prices and product characteristics will be sanctioned faster in markets where market information is readily and cheaply available to consumers. Since tied advice distribution channels pass on one-sided information and thus increase the search costs of consumers, the influence of the market share of tied advice (TDIST) on the variability of market shares of firms is expected to be negative. Moreover, if firms differ in their abilities to exploit new market opportunities, the variability of market shares of firms can expected to positively depend on the growth of the market potential. In order to account for this influence, the growth rate of the gross domestic product per capita (DGDPPC) was included in the regression as a proxy.

The fourth equation relates concentration (HERF) to regulation (REG) and demand factors as represented by the gross domestic product per capita (GDPPC) and its growth rate (DGDPPC). Since regulatory intervention typically raises entry barriers, highly regulated markets should be more concentrated. Life insurance markets of countries with low gross domestic product per capita tend to be young and concentrated markets. In contrast, the life insurance markets of the rich countries are "older". Market entry can be expected to have already eroded the above normal profits of the young and concentrated markets. Thus, concentration should be negatively correlated with the gross domestic product per capita GDPPC. The opposite should hold for the growth rate of the gross domestic product per capita DGDPPC, which serves again as a proxy for the growth of the market potential. 


\subsection{Regression results - structural form}

The first structural equation was estimated by pooling observations of the year 1987 over 12 contracts and 5 countries. The way this equation is specified indicates that it suffers the problem of multicollinearity. Thus, the actual regression equation was obtained by inserting the second structural equation into the first one. The results are given in Table 4.

All coefficients have the expected sign, except the coefficient of the interest rate, which is not significantly different from zero. The direct effect of regulation on the premium is calculated to be 61 percent. ${ }^{15}$

Table 4: Expected signs and estimated coefficients of the first structural equation ${ }^{16}$ explained : PREM

regressors: REG HERF LIFEEXP INTER CONST

$$
\begin{array}{ccccc}
(+) & (+/-) & (-) & (-) & \\
0.48 & 0.38 & -2.07 & 0.11 & 13.61 \\
(8.90)^{*} & (7.58)^{*} & (-16.09)^{*} & (0.94) & (23.81)^{*}
\end{array}
$$

$t$-ratios are in parentheses

number of observations: 60

F-statistic: 91

$\mathrm{R}^{2}: .87 \quad \overline{\mathrm{R}}^{2}: .86$

*: significant at the 1 percent level (two-tailed test).

Since the influence of the interest rate did not prove to be statistically significant from zero, is was removed from the equation. The results of the restricted model are given in Table 5 .

Table 5: Expected signs and estimated coefficients of the first structural equation (INTER excluded) ${ }^{17}$

explained: PREM

regressors: REG HERF LIFEEXP CONST

$$
\begin{array}{cccc}
(+) & (+/-) & (-) & \\
0.48 & 0.39 & -2.07 & 13.86 \\
(8.96)^{*} & (7.65)^{*} & (-16.09)^{*} & (27.02)^{*}
\end{array}
$$

$t$-ratios are in parentheses

number of observations: 60

$\mathbf{R}^{2}: .87 \quad \overline{\mathbf{R}}^{2}: .86$

F-statistic: 122

* : significant at the 1 percent level (two-tailed test).

15 The elasticity of the premium level on regulation is given by $\exp \left(\beta^{0}\right)-1=0.61$, while $\beta^{0}$ is the estimated parameter of REG. See Halvorsen and Palmquist (1980) for the interpretation of a dummy variable in a related context.

16 In order to control for heteroscedasticity, White s (1980) least squares covariance matrix estimator was applied.

17 Again, White's (1980) least squares covariance matrix estimator was used in order to control for heteroscedasticity. 
The direct effect of regulation is now given by an increase of the price of pure risk life insurance by 62 percent.

The second equation was estimated for the five-country sample with observations from the years 1986 and 1987 . Table 6 presents the results.

Table 6: Expected signs and estimated coefficients of the second structural equation ${ }^{18}$ explained: TDIST

regressors: REG HERF CONST

$$
(+) \quad(+/-)
$$

$$
(8.53)^{*}(-4.11)^{*}(7.51)^{*}
$$

$t$-ratios are in parentheses

number of observations: 10

$\mathbf{R}^{2}: .92 \quad \overline{\mathbf{R}}^{2}: .90$

$F$-statistic: 162

*: significant at the 1 percent level (two-tailed test).

The coefficients of the regulation variable REG and the income variable GDPPC are consistent with our hypotheses. The coefficient of the concentration variable is negative. Hence, the demand side effect dominates the supply side effect.

The regression results of the third equation are presented in Table 7. The observations for the five-country sample are also taken from the years 1986 and 1987.

All coefficients have the expected signs. In particular, the hypothesis that regulation reduces market share variability is supported. In addition, market shares tend to be more stable where tied advice distribution channels dominate.

18 Since no observations of TDIST for the year 1986 were available and since this variable is expected to change only slowly over time, the 1987 observations of TDIST served as proxies for the 1986 realisations. Moreover, since the market shares of the various distribution channels, as displayed in Table 1, are partially based on estimated figures, TDIST is obviously measured with error. This measurement error simply adds to the error term of the regression equation and does not change the statistical properties of the OLS estimators. 
Table 7: Expected signs and estimated coefficients of the third structural equation ${ }^{19}$

explained: VARMS

regressors: TDIST HERF DGDPPC CONST

$$
\begin{array}{cccc}
(-) & (-) & (+) & \\
-1.33 & -925.54 & 3883.89 & 83.95 \\
(-4.48)^{* *} & (-5.02)^{* *} & (5.35)^{* *} & (2.88)^{*}
\end{array}
$$

$t$-ratios are in parentheses

number of observations: 10

$\mathbf{R}^{2}: .93 \quad \overline{\mathbf{R}}^{2}: .89$

F-statistic: 28

*: significant at the 5 percent level (two-tailed test)

**: significant at the 1 percent level (two-tailed test).

Like the two preceding equations, the fourth equation was estimated for the years 1986 and 1987. The figures are given in Table 8.

Table 8: Expected signs and estimated coefficients of the fourth structural equation explained : HERF

regressors: REG GDPPC DGDPPC CONST

$$
\begin{array}{cccc}
(+) & (-) & (-) & \\
0.050 & -0.039 & -2.00 & 1.05 \\
(2.71)^{*} & (-3.69)^{* *} & (-2.13)^{*} & (3.99)^{* *}
\end{array}
$$

$t$-ratios are in parentheses

number of observations: 10

$\mathrm{R}^{2}: .72 \quad \overline{\mathbf{R}}^{2}: .58$

F-statistic : 25

*: significant at the 5 percent level (two-tailed test)

**: significant at the 1 percent level (two-tailed test).

The result support the hypothesis that regulation fosters concentration.

${ }^{19}$ As argued before, TDIST is a variable that is measured with error. Since TDIST serves as an independent variable in this equation, OLS would lead to inconsistent estimators of the structural coefficients. Therefore, an instrumental variable approach was chosen. In a first stage, TDIST was regressed on the instruments REG and HERF as proposed by the second structural equation of the model. In a second stage, OLS was applied to the third structural equation while the observations of TDIST had been replaced by the ex post predictions for TDIST from the first stage regression. For this 2SLS approach see Judge et al. (1985, pp. 728-730). 


\subsection{Regression results - reduced form}

In order to calculate the total effect of regulation on insurance premiums, the market share of tied advice and the market share variability, the reduced form of the model was estimated..$^{20}$ The results are presented in the following tables.

\section{Table 9: Expected signs and estimated coefficients of the reduced form of the premium level equation ${ }^{21}$}

explained: PREM

regressors: REG LIFEEXP GDPPC DGDPPC CONST

$$
\begin{array}{ccccc}
(+) & (-) & (+/-) & (+/-) & \\
0.77 & -2.07 & -0.26 & -0.10 & 19.45 \\
(12.16)^{*} & (-16.14)^{*} & (-7.20)^{*} & (-4.21)^{*} & (17.84)^{*}
\end{array}
$$

$t$-ratios are in parentheses

number of observations: 60

$\mathbf{R}^{2}: .87 \quad \overline{\mathbf{R}}^{2}: .86$

$F$-statistic: 91

*: significant at the 1 percent level (two-tailed test).

After transforming the parameter of the REG-variable as proposed in the preceding section, we obtain a premium increase due to regulation of 117 percent. Given the results of the structural estimation, we can conclude that the indirect influence of regulation via the increase in concentration amounts to 47 percent (or 55 points) of the total premium increase. Table 10 shows the observed premiums of the regulated countries and the predicted values for the case that they were unregulated. Eighteen out of 36 observed premium values lie above the ten percent (two-tailed) confidence interval while no observation falls below this interval.

The results of the reduced form estimation for the variable TDIST are given in Table 11. For the regulated countries, Table 12 presents the observed values of TDIST and the predicted values for the case that these countries were unregulated. A comparison of these columns shows that the market share of tied advice would be 43 percent lower if these countries were unregulated. Thus, regulation leads to less independent advice available for the consumer.

\footnotetext{
${ }^{20}$ Since the model is recursive, the reduced form for the variable HERF is given by the fourth structural equation as presented in section 5.1 .

${ }^{21}$ Expectations on the signs are based on the signs of the estimated parameters of the structural form. Again, White's (1980) least squares covariance matrix estimator was applied in order to control for heteroscedasticity.
} 
Table 10: Predicted pure risk life insurance premiums of the year 1987 for regulated countries for the case that they were unregulated

\begin{tabular}{|c|c|c|c|c|c|}
\hline COUNTRY & SEX & $\begin{array}{r}\text { AGE } \\
\text { GROUP }\end{array}$ & $\begin{array}{l}\text { CONTRACT } \\
\text { DURATION }\end{array}$ & $\begin{array}{l}\text { OBSERVED } \\
\text { PREMIUM }^{22}\end{array}$ & $\begin{array}{l}\text { PREDICTED } \\
\text { PREMIUM }\end{array}$ \\
\hline \multirow[t]{12}{*}{ GERMANY } & male & 25 & 5 & $161^{*}$ & 69 \\
\hline & male & 35 & 5 & 187 & 109 \\
\hline & male & 45 & 5 & 307 & 194 \\
\hline & female & 25 & 5 & $153^{*}$ & 54 \\
\hline & female & 35 & 5 & 174 & 81 \\
\hline & female & 45 & 5 & 274 & 133 \\
\hline & male & 25 & 10 & $172 *$ & 69 \\
\hline & male & 35 & 10 & 210 & 109 \\
\hline & male & 45 & 10 & 375 & 194 \\
\hline & female & 25 & 10 & $156^{*}$ & 54 \\
\hline & female & 35 & 10 & $195^{*}$ & 81 \\
\hline & female & 45 & 10 & $336^{*}$ & 133 \\
\hline \multirow[t]{12}{*}{ FRANCE } & male & 25 & 5 & 109 & 85 \\
\hline & male & 35 & 5 & 210 & 131 \\
\hline & male & 45 & 5 & 463 & 225 \\
\hline & female & 25 & 5 & 109 & 62 \\
\hline & female & 35 & 5 & $210^{*}$ & 92 \\
\hline & female & 45 & 5 & $463^{*}$ & 148 \\
\hline & male & 25 & 10 & 133 & 85 \\
\hline & male & 35 & 10 & 242 & 131 \\
\hline & male & 45 & 10 & $553^{*}$ & 225 \\
\hline & female & 25 & 10 & 133 & 62 \\
\hline & female & 35 & 10 & $242^{*}$ & 92 \\
\hline & female & 45 & 10 & $553^{*}$ & 148 \\
\hline \multirow[t]{12}{*}{ ITALY } & male & 25 & 5 & 209 & 112 \\
\hline & male & 35 & 5 & 290 & 177 \\
\hline & male & 45 & 5 & 536 & 314 \\
\hline & female & 25 & 5 & $209^{*}$ & 87 \\
\hline & female & 35 & 5 & $290^{*}$ & 131 \\
\hline & female & 45 & 5 & $536^{*}$ & 216 \\
\hline & male & 25 & 10 & 220 & 112 \\
\hline & male & 35 & 10 & 342 & 177 \\
\hline & male & 45 & 10 & $697^{*}$ & 314 \\
\hline & female & 25 & 10 & $220^{*}$ & 87 \\
\hline & female & 35 & 10 & $342^{*}$ & 131 \\
\hline & female & 45 & 10 & $697^{*}$ & 216 \\
\hline
\end{tabular}

${ }^{22}$ Values which are marked with an asterisk exceed the upper bound of the 10 percent (two-tailed) confidence interval of the predicted values. All other values lie within this interval. 
Table 11: Expected signs ${ }^{23}$ and estimated coefficients of the reduced form of TDIST explained: TDIST

$\begin{array}{ccccc}\text { regressors: } & \text { REG } & \text { GDPPC } & \text { DGDPPC } & \text { CONST } \\ & (+) & (+/-) & (+) & \\ 28.05 & 12.18 & 987.29 & -293.69 \\ & (5.03)^{*} & (3.88)^{*} & (3.49)^{*} & (-3.72)^{*}\end{array}$

$t$-ratios are in parentheses

number of observations: 10

$\mathbf{R}^{2}: .94 \quad \overline{\mathbf{R}}^{2}: .91$

F-statistic: 136

*: significant at the 1 percent level (two-tailed test).

Table 12: Predicted market shares of tied advice in regulated countries for the case that they were unregulated

$\begin{array}{lccc}\text { COUNTRY } & \text { YEAR } & \begin{array}{c}\text { OBSERVED } \\ \text { TDIST } 24\end{array} & \begin{array}{c}\text { PREDICTED } \\ \text { TDIST }\end{array} \\ \text { GERMANY } & 1986 & 81 & 50 \\ \text { FRANCE } & 1986 & 58 & 29 \\ \text { ITALY } & 1986 & 56 & 27 \\ \text { GERMANY } & 1987 & 81 & 47 \\ \text { FRANCE } & 1987 & 58 & 39 \\ \text { ITALY } & 1987 & 56 & 30\end{array}$

Finally, the reduced form equation for the market share variability was estimated. The results are presented in Table 13. Table 14 displays the observed values for the market share variability in the regulated countries as well as the predictions for the case that these countries were unregulated. As the figures show, the predicted values for the non-regulation case are about eight times higher than the observed values.

23 Expectations are based on the signs of the estimated parameters of the structural form.

${ }^{24}$ All the observed values exceed the upper bound of the 10 percent (two-tailed) confidence interval of the predicted values. 
Table 13: Expected signs ${ }^{25}$ and estimated coefficients of the reduced form of VARMS explained: VARMS

regressors: REG GDPPC DGDPPC CONST

$\begin{array}{cccc}(-) & (+) & (+) & \\ -77.57 & 13.10 & 4733.40 & -346.19 \\ (-3.60)^{*} & (1.08) & (4.34)^{*} & (-1.13)\end{array}$

$t$-ratios are in parentheses

number of observations: 10

$\mathbf{R}^{2}: .84 \quad \overline{\mathbf{R}}^{2}: .77$

F-statistic: 12.6

*: significant at the 1 percent level (two-tailed test).

Table 14: Predicted variability of market shares in regulated countries for the case that they were unregulated

$\begin{array}{lccc}\text { COUNTRY } & \text { YEAR } & \begin{array}{c}\text { OBSERVED } \\ \text { VARMS }\end{array} & \begin{array}{c}\text { PREDICTED } \\ \text { VARMS }\end{array} \\ \text { GERMANY } & 1986 & 2.2^{*} & 108.9 \\ \text { FRANCE } & 1986 & 14.7 & 60.3 \\ \text { ITALY } & 1986 & 8.7^{*} & 109.8 \\ & & & \\ \text { GERMANY } & 1987 & 4.8^{*} & 75.6 \\ \text { FRANCE } & 1987 & 25.5^{*} & 84.4 \\ \text { ITALY } & 1987 & 11.3^{*} & 93.6\end{array}$

\section{Conclusions}

This cross section study on the insurance markets of five selected European countries shows that the regulatory framework is of major influence on prices, market shares of distribution channels, variability of market shares as well as market concentration. Premiums for pure risk life insurance prove to be on average 117 percent higher in countries with pervasive and strict regulations. About half of this increase can be attributed to the influence of regulation on market concentration. Moreover, regulation fosters tied advice distribution channels and thus tends to diminish the amount of independent information available to consumers. Finally, it is shown that market share volatility is drastically reduced by regulatory intervention.

25 Expectations are based on the signs of the estimated parameters of the structural form.

26 Values which are marked with an asterisk fall below the lower bound of the 10 percent (twotailed) confidence interval of the predicted values. The other value lies within this interval. 


\section{REFERENCESS}

ANDERSON CONSULTING (1990) Insurance in a Changing Europe 1990-1995, Special Report No. 2068.

EISEN, R., MÜLLER, W. and ZWEIFEL, P. (1993) Entrepreneurial Insurance: A New Paradigm for Deregulated Markets. Geneva Papers on Risk and Insurance 18, pp. 3-56.

ELLIS, H. (1989) Regulation of Insurance in the UK and Ireland. Dordrecht.

FARNY, D. (1989) Erwartungen europäischer Versicherer an den Binnenmarkt, Zeitschrift für die gesamtc Versicherungswissenschaft Heft 1/2 1989, pp. 67-106.

FAURE, M. and VAN DEN BERGH, R. (1989) Restrictions of Competition on the Belgian Insurance Markets and the Applicability of Antitrust Law, University of Antwerp. August 1989. Mimeo.

FINSINGER, J., HAMMOND, E. and TAPP, J. (1985) Insurance : Competition or Regulation? Institute for Fiscal Studies Report No. 19. London.

FINSINGER, J. and PAULY, M. V., eds. (1985) The Economics of Insurance Regulation. Basingstoke and New York.

HALVORSEN, R. and PALMQUiST, R. (1980) The Interpretation of Dummy Variables in Semilogarithmic Equations, American Economic Review 70, pp. 474-475.

HARRINGTON S. (1984) The Impact of Rate Regulation on Prices and Underwriting Results in the Property-Liability Insurance Industry: A Survey, Journal of Risk and Insurance 51, pp. 577-623.

JUDGE, G. et al. (1985) The Theory and Practice of Econometrics. New York.

L'ARGUS, Journal international des assurances, No. 6111, 1989.

PAULY, M. V., KUNREUTHER, H. and KLEINDORFER, P. (1986) Regulation and Quality Competition in the US Insurance Industry; in: J. Finsinger and M. V. Pauly (eds.) The Economics of Insurance Regulation, Basingstoke and New York, pp. 65-110.

PRICE WATERHOUSE (1988) The Cost of 'Non-Europe' in Financial Services. Commission of the European Communities.

STATISTISCHES BUNDESAMT, ed. (1990) Statistisches Jahrbuch 1990 für die Bundesrepublik Deutschland. Suttgart.

UNITED NATIONS (1990a) 1987 Statistical Yearbook. New York.

UNITED NATIONS (1990b) 1988 Demographic Yearbook. New York.

VAN DEN BERGHE, L. (1989) (De)Regulation of Insurance Markets; in : H. Loubergé (ed.) Risk, Information and Insurance. Boston.

WHITE, H. (1980) A Heteroskedasticity-Consistent Covariance Matrix Estimator and a Direct Test for Heteroskedasticity. Econometrica 48, pp. 817-838.

ZWEIFEL, P. and GHERMI, P. (1990) Exclusive vs. Independent Agencies: A Comparison of Performance, Geneva Papers on Risk and Insurance, Theory 15, pp. 171-192. 